\title{
Chemotherapy Induced Nausea and Vomiting: Fear Makes the Wolf Bigger than $\mathrm{He}$ is
}

\section{Mansi Sharma and Jyoti Bajpai*}

Medical oncologist, Tata Memorial Cancer Centre, Mumbai, India

“Corresponding author: Jyoti Bajpai, Medical oncologist, Tata Memorial Cancer Centre, Mumbai, India, Tel: +919920640040; E-mail: dr_jyotibajpai@yahoo.co.in

Received date: December 19, 2016; Accepted date: January 18, 2017; Published date: January 23, 2017

Copyright: ( 2017 Sharma M, et al. This is an open-access article distributed under the terms of the Creative Commons Attribution License, which permits unrestricted use, distribution, and reproduction in any medium, provided the original author and source are credited.

\begin{abstract}
Chemotherapy induced nausea and vomiting (CINV) is one of the most feared and severe side effects of cancer treatment. It is broadly categorised as anticipatory (a conditioned reflex, due to past experience, generally triggered by same stimuli), acute (within 24 hours of chemotherapy administration), delayed (after 24 hours and lasting up to 7 days of chemotherapy), breakthrough (inspite of primary prophylaxis for CINV), and refractory (unresponsive to prophylactic and breakthrough medications). The chemotherapeutic regimens are having varying potential (high, moderate, low, or minimal) for CINV. Incidence and timing of CINV depends upon the emetogenic potential of chemotherapy and also patient factors. This perspective highlights the underlying mechanism of CINV, state of the art therapeutic options and nuances in the field to better control this dreaded complication and in turn enhance the quality of life of these patients.
\end{abstract}

\section{Article}

One of the most important complications of cancer therapy is development of chemotherapy induced nausea and vomiting (CINV). It can be highly debilitating to the patient, leading to decreased quality of life. This has various therapeutic implications, and can lead to the patient receiving suboptimal therapy. CINV can cause poor compliance with therapy, nutritional deficiencies, metabolic derangements, need for in patient management, and can also result in mechanical issues like wound dehiscence and esophageal tears [1-3].

$\mathrm{CINV}$ is divided into three main subtypes, mainly acute, delayed and anticipatory. Acute emesis usually begins a few minutes to few hours after chemotherapy, peaks within four to six hours, and usually resolves within the first twenty four hours. Delayed emesis develops more than twenty four hours after chemotherapy, especially with drugs like cisplatin, carboplatin, doxorubicin, and cyclophosphamide [4-6]. Anticipatory emesis develops in patients prior to their next chemotherapy cycle as a conditioned response $[7,8]$. It occurs mostly in patients who have had poor control of emesis during previous chemotherapy cycles. Another type of CINV is known as breakthrough nausea and vomiting, which occurs in spite of prophylactic medications [9]. Refractory CINV is defined as vomiting and/or nausea occurring in subsequent chemotherapy cycles when prophylactic and/or rescue therapy has failed in previous cycles [10].

There are two main pathways through which chemotherapy can cause emesis [11,12]. Acute CINV is mostly caused by activation of the peripheral pathway. Chemotherapy drugs lead to activation of neurotransmitter receptors including 5HT3 receptors in the gastrointestinal tract. This leads to the transmission of afferent impulses to the vomiting centre, activation of which leads to vomiting. Efferent signals are transmitted via the vagus nerve to the salivation centre, abdominal muscles, respiratory centre and cranial nerves [13]. The central pathway is mostly responsible for causing delayed CINV. The vomiting centre is stimulated by afferent impulses from the chemoreceptor trigger zone and cerebral cortex [14,15]. Various neurotransmitters and their receptors are involved in these pathways, most importantly dopamine, 5HT 3 and substance P [16]. Most antiemetic drugs target these neurotransmitters and their receptors. Others include neurokinin-1, corticosteroids, acetylcholine, histamine, opioid and cannabinoid receptors [17].

Chemotherapy drugs are classified according to their intrinsic emetogenicity. A classification scheme was developed by Hesketh and colleagues, which defined the emetogenicity of individual drugs as well combination chemotherapy regimens [18]. A modification of this classification proposed by Grunberg is presently in use $[19,20]$. This classification divides chemotherapy drugs into four main subtypes based on the risk of developing emesis in the absence of antiemetic prophylaxis (Tables 1 and 2). More than $90 \%$ patients develop acute emesis after administration of highly emetogenic chemotherapy. Similarly, after administration of moderately emetogenic chemotherapy, $30-90 \%$ patients develop acute emesis and 10-30\% do so after low emetogenic chemotherapy administration. In drugs or chemotherapy regimens classified as minimal emetogenic, less than $10 \%$ patients develop acute emesis. The emetogenic potential of some chemotherapy agents may vary as per the dose used [18]. Cisplatin is classified as highly emetogenic at doses of $\geq 50 \mathrm{mg} / \mathrm{m}^{2}$, and moderately emetogenic at doses of $<50 \mathrm{mg} / \mathrm{m}^{2}$ [18]. Tables 1 and 2 lists the other chemotherapeutic drugs with emetogenicity varying as per doses.

\begin{tabular}{|l|l|l|}
\hline High & Moderate & Low \\
\hline Anthracycline/cyclophosphamide combination & Aldesleukin $>12-15$ million $\mathrm{IU} / \mathrm{m}^{2}$ & Ado- trastuzumab emtansine \\
\hline
\end{tabular}


Citation: Sharma M, Bajpai J (2017) Chemotherapy Induced Nausea and Vomiting: Fear Makes the Wolf Bigger than He is. J Carcinog Mutagen 8: 282. doi:10.4172/2157-2518.1000282

Page 2 of 7

\begin{tabular}{|c|c|c|c|}
\hline Carmustine $>250 \mathrm{mg} / \mathrm{m}^{2}$ & Amifostine $>300 \mathrm{mg} / \mathrm{m}^{2}$ & Amifostine $\leq 300 \mathrm{mg} / \mathrm{m}^{2}$ & Asparaginase \\
\hline Cisplatin & Arsenic trioxide & Aldesleukin $\leq 12$ million $\mathrm{IU} / \mathrm{m}^{2}$ & Bevacizumab \\
\hline Cyclophosphamide $>1500 \mathrm{mg} / \mathrm{m}^{2}$ & Azacitidine & Belinostat & Bleomycin \\
\hline Dacarbazine & Bendamustine & Blinatumomab & Bortezomib \\
\hline Doxorubicin $\geq 60 \mathrm{mg} / \mathrm{m}^{2}$ & Busulfan & Brentuximab vedotin & Cetuximab \\
\hline Epirubicin $>90 \mathrm{mg} / \mathrm{m}^{2}$ & Carboplatin & Cabazitaxel & Cladribine \\
\hline Ifosfamide $\geq 2 \mathrm{~g} / \mathrm{m}^{2}$ per dose & Carmustine $\leq 250 \mathrm{mg} / \mathrm{m}^{2}$ & Carfilzomib & Cytarabine $<100 \mathrm{mg} / \mathrm{m}^{2}$ \\
\hline Mechlorethamine & Clofarabine & $\begin{array}{l}\text { Cytarabine (low dose) } 100-200 \\
\mathrm{mg} / \mathrm{m}^{2}\end{array}$ & Daratumumab \\
\hline \multirow[t]{26}{*}{ Streptozocin } & Cyclophosphamide $\leq 1500 \mathrm{mg} / \mathrm{m}^{2}$ & Docetaxel & Decitabine \\
\hline & Cytarabine $>200 \mathrm{mg} / \mathrm{m}^{2}$ & Doxorubicin (liposomal) & Denileukin diftitox \\
\hline & Dactinomycin & Eribulin & Dexrazoxane \\
\hline & Daunorubicin & Etoposide & Elotuzumab \\
\hline & Dinutuximab & Fluorouracil & Fludarabine \\
\hline & Doxorubicin $<60 \mathrm{mg} / \mathrm{m}^{2}$ & Floxuridine & $\begin{array}{l}\text { Interferon alfa } \leq 5 \text { million } \\
\mathrm{IU} / \mathrm{m}^{2}\end{array}$ \\
\hline & Epirubicin $\leq 90 \mathrm{mg} / \mathrm{m}^{2}$ & Gemcitabine & Ipilimumab \\
\hline & idarubicin & Interferon alfa $>5-<10$ million $\mathrm{IU} / \mathrm{m}^{2}$ & Methotrexate $\leq 50 \mathrm{mg} / \mathrm{m}^{2}$ \\
\hline & Ifosfamide $<2 \mathrm{~g} / \mathrm{m}^{2}$ per dose & Irinotecan ( liposomal) & Nelarabine \\
\hline & Interferon alfa $\geq 10$ million $\mathrm{IU} / \mathrm{m}^{2}$ & Ixabepilone & \\
\hline & Irinotecan & $\begin{array}{l}\text { Methotrexate }>50 \quad \mathrm{mg} / \mathrm{m}^{2}-<250 \\
\mathrm{mg} / \mathrm{m}^{2}\end{array}$ & Obinutuzumab \\
\hline & Melphalan & Mitomycin & Ofatumumab \\
\hline & Methotrexate $\geq 250 \mathrm{mg} / \mathrm{m}^{2}$ & Mitoxantrone & Panitumumab \\
\hline & Oxaliplatin & Necitumumab & Pegaspargase \\
\hline & Temozolamide & Omacetaxine & Peginterferon \\
\hline & Trabectedin & Paclitaxel and nabpaclitaxel & Pembrolizumab \\
\hline & & Pemetrexed & Pertuzumab \\
\hline & & Pentostatin & Ramucirumab \\
\hline & & Pralatrexate & Rituximab \\
\hline & & Romidepsin & Siltuximab \\
\hline & & Talimogene laherparepvec & Temsirolimus \\
\hline & & Thiotepa & Trastuzumab \\
\hline & & Topotecan & Valrubicin \\
\hline & & Ziv-aflibercept & Vinblastine \\
\hline & & & Vincristine \\
\hline & & & Vincristine (liposomal) \\
\hline
\end{tabular}




\begin{tabular}{|l|l|l|}
\hline & & Vinorelbine \\
\hline
\end{tabular}

Table 1: Classification of Intravenous chemotherapy drugs/regimens based on emitogenic potential.

\begin{tabular}{|c|c|}
\hline High /moderate & Low /Minimal \\
\hline Altretamine & Afatinib \\
\hline Busulfan & Alectinib \\
\hline Ceritinib & Axitinib \\
\hline Crizotinib & Bexarotene \\
\hline Cyclophosphamide $\geq 100 \mathrm{mg} / \mathrm{m}^{2} /$ day & Bosutinib \\
\hline Estramustine & Busulfan (<4 mg/day) \\
\hline Etoposide & Cabozantinib \\
\hline Lenvatinib & Capecitabine \\
\hline Lomustine (single day) & Chlorambucil \\
\hline Mitotane & Cobimetinib \\
\hline Olaparib & $\begin{array}{l}\text { Cyclophosphamide } \\
\mathrm{mg} / \mathrm{m}^{2} / \text { day }\end{array}$ \\
\hline Panobinostat & Dasatinib \\
\hline Procarbazine & Dabrafenib \\
\hline Temozolomide (>75 mg/m²/day) & Erlotinib \\
\hline \multirow[t]{19}{*}{ Trifluridine/tipiracil } & Everolimus \\
\hline & Fludarabine \\
\hline & Gefitinib \\
\hline & Hydroxyurea \\
\hline & Ibrutinib \\
\hline & Idelalisib \\
\hline & Imatinib \\
\hline & Ixazomib \\
\hline & Lapatinib \\
\hline & Lenalidomide \\
\hline & Melphalan \\
\hline & Mercaptopurine \\
\hline & Methotrexate \\
\hline & Nilotinib \\
\hline & Osimertinib \\
\hline & Palbociclib \\
\hline & Pazopanib \\
\hline & Pomalidomide \\
\hline & Ponatinib \\
\hline
\end{tabular}

\begin{tabular}{|l|l|}
\hline & Regorafenib \\
\hline & Ruxolitinib \\
\hline & Sonidegib \\
\hline & Sorafenib \\
\hline & Sunitinib \\
\hline & Temozolamide $\left(\leq 75 \mathrm{mg} / \mathrm{m}^{2} / \mathrm{day}\right)$ \\
\hline & Thalidomide \\
\hline & Thioguanine \\
\hline & Topotecan \\
\hline & Trametinib \\
\hline & Tretinoin \\
\hline & Vandetanib \\
\hline & Vemurafenib \\
\hline & Vismodegib \\
\hline & Vorinostat \\
\hline
\end{tabular}

Table 2: Classification of oral chemotherapy drugs based on emitogenic potential.

Complete prevention of CINV should be the goal for any antiemetic regimen. Four major classes of agents are used for the same, either as a single agent, or as part of a combination regimen. These are type three 5hydroxytryptamine (5HT3) receptor antagonists, the neurokinin 1 receptor (NK1R) antagonists, glucocorticoids and the antipsychotic medication olanzapine.

Various studies have demonstrated that 5HT3 antagonists used in combination with dexamethasone are more effective for the treatment and prophylaxis of CINV, with a better side effect profile than high dose metoclopramide plus dexamethasone [21-24]. The first generation 5HT3 antagonists include ondansetron, granisetron, dolasetron, ramosetron and tropisetron. Commonly used are ondansetron and granisetron. They appear equally effective in preventing acute or delayed CINV [25]. Oral formulations are equally effective as intravenous (IV) formulations [26-28]. Common side effects include headache, malaise, constipation and ECG changes. All first generation 5HT3 antagonists can cause ECG interval changes. These are most commonly seen after one to two hours and usually return to baseline within 24 hours [29-31]. Most changes are insignificant; however there have been case reports of QTc prolongation leading to development of serious arrhythmias like torsade de pointes $[29,31,32]$. ECG changes have not yet been reported in transdermal and extended release subcutaneous granisetron formulations $[33,34]$. Care must be taken while prescribing 5HT3 receptor antagonists in patients with cardiac disease, bradyarrythmias, and older patients, those with renal impairment and on other drugs known to cause QT interval prolongation. ECG monitoring and QTc 
interval monitoring must be done regularly in such patients, and dyselectrolytemias should be corrected. Oral dosing of ondansetron has fewer propensities for causing arrhythmias as compared to the IV dosing [35]. As per the FDA recommendations single IV dose of ondansetron should not exceed $16 \mathrm{mg}$ and its use should be avoided in patients with congenital long QT syndrome [36].

Palonosetron is a second generation 5-HT3 receptor antagonist, with a 30 to 100 fold higher affinity for the receptor, as well as a long half-life of 40 hours [37]. As seen in several large randomised phase three trials, palonosetron is equally effective when compared to ondansetron [38], granisetron [39] and dolasetron [40] in preventing acute emesis and more effective in preventing delayed emesis. Importantly, QTc prolongation has not been described with palonosetron [41,42]. Updated antiemetic guidelines from the American Society of Clinical Oncology (ASCO) and the National Comprehensive Cancer Network (NCCN) recommend palonosetron as the preferred $5 \mathrm{HT} 3$ antagonist for patients who receive moderately emetogenic chemotherapy [43-45].

Neurokinin 1 (NK1) receptor antagonists include aprepitant and fosaprepitant. Aprepitant selectively blocks the binding of substance P at the NK1 receptor in the central nervous system and fosaprepitant is a parenteral water soluble prodrug of aprepitant. Various trials have evaluated the efficacy of these drugs in patients receiving highly emetogenic chemotherapy regimens. A metaanalysis of 17 trials evaluated the benefit of combining aprepitant with standard antiemetics in highly and moderately emetic chemotherapy regimens. The addition of aprepitant was associated with a significant improvement in the rate of complete response, i.e. absence of emesis and no need for rescue antiemetics [46].

Various other trials have demonstrated similar results in highly emetic chemotherapy regimens $[47,48]$. Aprepitant also significantly improved the ability to prevent nausea and vomiting in carboplatin containing regimens when combined with dexamethasone and a 5HT3 receptor antagonist [49-52]. Aprepitant needs to be combined with dexamethasone and a 5HT3 receptor antagonist to provide maximum efficacy as compared with only aprepitant and dexamethasone, especially in cisplatin based regimens [53]. Aprepitant is a substrate of, and induces as well as inhibits cytochrome p450 3A4 (CYP3A4). Is also induces CYP2C9 [54]. Hence care must be taken while using other drugs which are known to be metabolised by these enzymes.

Netupitant is a highly selective NK1 receptor antagonist and its oral fixed drug combination with palonosetron-NEPA, containing $300 \mathrm{mg}$ of netupitant and $0.5 \mathrm{mg}$ of palonosetron has been studied in combination with dexamethasone in patients receiving moderately or highly emetogenic chemotherapy. FDA has approved NEPA for the prevention of CINV based on the results of 2 randomised trials [55,56], which showed superior prevention of CINV by NEPA and steroid combination as compared to a combination of aprepitant, 5HT3 antagonist and dexamethasone.

Dexamethasone is an important component of most anti-emetic regimens. A number of randomised trials have established efficacy either as a single agent or in combination. Dexamethasone was found to be superior to placebo or no treatment with regard to both acute and delayed emesis in a meta-analysis of 32 randomised trials in patients receiving moderately or highly emetogenic chemotherapy regimens [57].

Olanzapine is an atypical antipsychotic drug, with antagonism of multiple receptors including dopamine D2 receptors, serotonin, 5HT2 receptors and acetylcholine- muscarinic receptors. Various trials have explored the efficacy of olanzapine in preventing both acute and delayed CINV. A metaanalysis of 10 randomised trials in patients receiving highly or moderately emetogenic chemotherapy [58] demonstrated the efficacy of olanzapine in preventing both acute and delayed emesis. However some of these studies did not use standard antiemetic regimens, especially use of a NK1 receptor antagonist. Two phase three trials have shown the efficacy of adding olanzapine to regimens containing NK1R antagonist, a 5HT3 antagonist, and a glucocorticoid $[59,60]$. The drug seems especially beneficial in preventing delayed nausea. Guidelines have included olanzapine in antiemetic regimens for both moderately and highly emetic chemotherapy [45].

While prescribing antiemetics, it is important to know the period of risk, and hence use drugs for the appropriate amount of time. The risk of vomiting lasts for 3 days for highly emetogenic regimens and for 2 days for moderately emetogenic chemotherapy regimens [45]. Antiemetic therapy is based on the drug with the highest emetic risk in patients receiving multi drug regimens.

NCCN guidelines recommend regimens containing combinations of 5HT3 antagonist, dexamethasone, NK1 receptor antagonist and olanzapine for highly emetogenic chemotherapy regimens [45]. Aprepitant is used at an oral dosage of $125 \mathrm{mg}$ on day $1,80 \mathrm{mg}$ on day 2 and 3. If fosaprepitant is used, it is given as a single IV dose of 150 $\mathrm{mg}$ on day 1 only. Dexamethasone is used either as an oral or IV dose of $12 \mathrm{mg}$ on day 1 . Either dolasetron $100 \mathrm{mg}$, granisetron $0.01 \mathrm{mg} / \mathrm{kg}$ ( $\max 1 \mathrm{mg}$ ) IV, ondansetron 16-24 mg PO once or 8-16 mg IV once or palonosetron $0.25 \mathrm{mg}$ IV once on day 1 can be used. Dexamethasone is continued at $8 \mathrm{mg} \mathrm{PO} / \mathrm{IV}$ daily from day 2 to day 4. MASCC-ESMO guidelines recommend similar regimens [61]. An alternate regimen consists of olanzapine $10 \mathrm{mg}$ orally on days 1 to 4 with palonosetron $0.25 \mathrm{mg}$ and dexamethasone $20 \mathrm{mg} \mathrm{IV}$ on day 1 . A third regimen consists of giving NEPA on day 1 , with dexamethasone $12 \mathrm{MG} \mathrm{PO/IV}$ on day 1 , continued as $8 \mathrm{mg} \mathrm{PO} / \mathrm{IV}$ on days 2 to 4 . Lorazepam, can also be added, as it decreases anxiety, and is especially useful to prevent anticipatory nausea and vomiting [62]. Antacids (proton pump inhibitors, H2 blockers) may also be added, especially if patients have dyspepsia.

For chemotherapy regimens at moderate risk for emesis, NCCN guidelines recommend a 5 HT3 antagonist, steroid with or without a NK1 receptor antagonist on the first day [45]. If an NK1 antagonist is not used, then either $5 \mathrm{HT} 3$ receptor antagonists or steroids are to be given on day 2 and day 3 . If an NK 1 receptor antagonist is given on day 1 , then steroids may be given on days 2 and 3. MASCC-ESMO as well as NCCN recommends adding NK 1 receptor antagonists to patients receiving carboplatin based chemotherapy [45,61]. Patients receiving chemotherapy drugs or regimens with low risk of emesis should receive either dexamethasone or metoclopramide or a 5HT3 receptor antagonist, repeated daily in case of multi day protocols. Patients receiving chemotherapy with minimal emetogenic potential do not require any routine prophylaxis [45].

Breakthrough nausea and vomiting may be treated with adding an agent from a different drug class [9]. Refractory CINV may need a change in the prophylactic regimen. Various drugs include olanzapine, metoclopramide, haloperidol, lorazepam, and cannabinoids [45]. The antiemetic regimen used should be reassessed and it should be confirmed that adequate drugs were used according to the risk of emetogenicity in the first place. The appropriate drugs should be added if not used initially. Other potential causes causing breakthrough 
nausea and vomiting should be excluded. These include dyselectrolytemia, bowel obstruction or brain metastasis [45]. A Cochrane database analysis review of 23 randomised trials found that patients who received cannabis based medicines experienced lesser nausea and vomiting as compared to conventional anti-emetics. More patients experienced side effects, in spite of which cannabis based medications were preferred over conventional medications [63]. There may be a place for these in patients with refractory nausea and vomiting. Similarly, low alcohol consumption is a known risk factor for increased CINV along with various other risk factors like female patients, younger age, presence of anxiety [64-66]. These factors are currently not used to choose or change the antiemetic regimens. Randomised controlled trials or the development of nomograms based on these risk factors may have a role in personalised anti-emetic regimens in the future.

\section{Conclusions}

Oncology care providers are concerned about oncologic outcome so much that they start undermining the complications of therapy which directly affects quality of life. One must be careful in assessing the real depth of the iceberg and not only the tip when handling one of the distressing complications of chemotherapy like CINV. Adequate control of CINV can lead to better patient compliance and might be having bearing on ultimate outcomes also. The optimization of the treatment should be made according to the emetogenicity of the chemotherapy regimen with different permutation-combination of NK1 receptor antagonist, 5HT3 receptor antagonist and corticosteroid. Ancillary drugs like olanzapine and lorazepam may also prove beneficial and should be judiciously used to their full potential. There might be scope for personalised management of CINV based on individual risk factors. Let's not allow the fear of CINV to make "the wolf bigger than he is!"

\section{References}

1. Ingle RJ, Burish TG, Wallston KA (1984) Conditionability of cancer chemotherapy patients. Oncol Nurs Forum 11: 97-102.

2. Richardson JL, Marks G, Levine A (1988) The influence of symptoms of disease and side effects of treatment on compliance with cancer therapy. J Clin Oncol 6: 1746-1752.

3. Mitchell EP (1992) Gastrointestinal toxicity of chemotherapeutic agents. Semin Oncol 19: 566-579.

4. Kris MG, Gralla RJ, Clark RA, Tyson LB, O'Connell JP, et al. (1985) Incidence, course, and severity of delayed nausea and vomiting following the administration of high-dose cisplatin. J Clin Oncol 3: 1379-1384.

5. Roila F, Boschetti E, Tonato M (1991) Predictive factors of delayed emesis in cisplatin-treated patients and antiemetic activity and tolerability of metoclopramide or dexamethasone. A randomised single blind study. Am J Clin Oncol 14: 238-242.

6. Kaizer L, Warr D, Hoskins P (1994) Effect of schedule and maintenance on the antiemetic efficacy of ondansetron combined with dexamethasone in acute and delayed nausea and emesis in patients receiving moderately emetogenic chemotherapy: a phase III trial by the National Cancer Institute of Canada Clinical Trials Group. J Clin Oncol 12: 1050.

7. Moher D, Arthur AZ, Pater JL (1984) Anticipatory nausea and/or vomiting. Cancer Treat Rev 11: 257-264.

8. Jacobsen PB, Redd WH (1988) The development and management of chemotherapy-related anticipatory nausea and vomiting. Cancer Invest 6: 329-336.

9. Roila F, Hesketh PJ, Herrstedt J (2006) Prevention of chemotherapy- and radiotherapy- induced emesis: results of the 2004 Perugia International Antiemetic Consensus Conference. Ann Oncol 17: 20-28.
10. Navari RM (2013) Management of chemotherapy-induced nausea and vomiting : focus on newer agents and new uses for older agents. Drugs 73: 249-262.

11. Hesketh PJ (2008) Chemotherapy-induced nausea and vomiting. N Engl J Med 358: 2482-2494.

12. Janelsins MC, Tejani MA, Kamen C (2013) Current pharmacotherapy for chemotherapy- induced nausea and vomiting in cancer patients. Expert Opin Pharmacother 14: 757.

13. Craig JB, Powell BL (1987) The management of nausea and vomiting in clinical oncology. Am J Med Sci 293: 34-44.

14. Borison HL, Wang SC (1953) Physiology and pharmacology of vomiting. Pharmacol Rev 5: 193-230.

15. Wang SC (1965) Emetic and antiemetic drugs. In: Physiological pharmacology: A comprehensive treatise, Root WS, Hofmann FG (Eds), Academic Press, New York II: 225.

16. Leslie RA (1985) Neuroactive substances in the dorsal vagal complex of the medulla oblongata: nucleus of the tractus solitarius, area postrema, and dorsal motor nucleus of the vagus. Neurochem Int 7: 191.

17. Dodds LJ (1985) The control of cancer chemotherapy-induced nausea and vomiting. J Clin Hosp Pharm 10: 143-166.

18. Hesketh PJ, Kris MG, Grunberg SM, Beck T, Hainsworth JD, et al. (1997) Proposal for classifying the acute emetogenicity of cancer chemotherapy. J Clin Oncol 15: 103-109.

19. Grunberg SM, Osoba D, Hesketh PJ, Gralla RJ, Borjeson S, et al. (2005) Evaluation of new antiemetic agents and definition of antineoplastic agent emetogenicity--an update. Support Care Cancer 13: 80-84.

20. Grunberg SM, Warr D, Gralla RJ, Rapoport BL, Hesketh PJ, et al. (2011) Evaluation of new antiemetic agents and definition of antineoplastic agent emetogenicity--state of the art. Support Care Cancer 19 Suppl 1: S43-47.

21. Heron JF, Goedhals L, Jordaan JP (1994) Oral granisetron alone and in combination with dexamethasone: a double- blind randomized comparison against high- dose metoclopramide plus dexamethasone in prevention of cisplatin- induced emesis. The Granisetron Study Group. Ann Oncol 5:579.

22. Chevallier B (1990) Efficacy and safety of granisetron compared with high- dose metoclopramide plus dexamethasone in patients receiving high- dose cisplatin in a single- blind study. The Granisetron Study Group. Eur J Cancer 26: S33.

23. Warr D, Wilan A, Venner P (1992) A randomised, double- blind comparison of granisetron with high- dose metoclopramide, dexamethasone and diphenhydramine for cisplatin- induced emesis. An NCI Canada Clinical Trials Group Phase III Trial. Eur J Cancer 29A: 33.

24. Chevallier B, Cappelaere P, Splinter T (1997) A double- blind, multicentre comparison of intravenous dolasetron mesilate and metoclopramide in the prevention of nausea and vomiting in cancer patients receiving highdose cisplatin chemotherapy. Support Care Cancer 5: 22.

25. del Giglio A, Soares HP, Caparroz C, Castro PC (2000) Granisetron is equivalent to ondansetron for prophylaxis of chemotherapy-induced nausea and vomiting: results of a meta-analysis of randomized controlled trials. Cancer 89: 2301-2308.

26. Gandara DR, Roila F, Warr D (1998) Consensus proposal for 5HT3 antagonists in the prevention of acute emesis related to highly emetogenic chemotherapy. Dose, schedule, and route of administration. Support Care Cancer 6: 237.

27. Perez EA, Hesketh P, Sandbach J (1998) Comparison of single- dose oral granisetron versus intravenous ondansetron in the prevention of nausea and vomiting induced by moderately emetogenic chemotherapy: a multicenter, double- blind, randomized parallel study. J Clin Oncol 16: 754.

28. Gralla RJ, Navari RM, Hesketh PJ (1998) Single- dose oral granisetron has equivalent antiemetic efficacy to intravenous ondansetron for highly emetogenic cisplatin- based chemotherapy. J Clin Oncol 16: 1568. 
29. Navari RM, Koeller JM (2003) Electrocardiographic and cardiovascular effects of the 5- hydroxytryptamine3 receptor antagonists. Ann Pharmacother 37: 1276 .

30. Pinarli FG, Elli M, Dagdemir A (2006) Electrocardiographic findings after 5HT3 receptor antagonists and chemotherapy in children with cancer. Pediatr Blood Cancer 47: 567.

31. Keller GA, Ponte ML, Di Girolamo G (2010) Other drugs acting on nervous system associated with QT- interval prolongation. Curr Drug Saf 5: 105 .

32. Turner S, Mathews L, Pandharipande P, Thompson R (2007) Dolasetroninduced torsades de pointes. J Clin Anesth 19: 622-625.

33. Mason JW, Selness DS, Moon TE, O'Mahony B, Donachie P, et al. (2012) Pharmacokinetics and repolarization effects of intravenous and transdermal granisetron. Clin Cancer Res 18: 2913-2921.

34. Mason JW, Moon TE, O'Boyle E, Dietz A (2014) A randomized, placebocontrolled, four- period crossover, definitive QT study of the effects of APF530 exposure, high- dose intravenous granisetron, and moxifloxacin on QTc prolongation. Cancer Manag Res 6: 181.

35. Brygger L, Herrstedt J, Academy of Geriatric Cancer Research (AgeCare) (2014) 5-Hydroxytryptamine3 receptor antagonists and cardiac side effects. Expert Opin Drug Saf 13: 1407-1422.

36. United States Food and Drug Administration (2012) FDA Drug Safety Communication: New information regarding QT prolongation with ondansetron (Zofran).

37. Grunberg SM, Koeller JM (2003) Palonosetron: a unique 5-HT3-receptor antagonist for the prevention of chemotherapy-induced emesis. Expert Opin Pharmacother 4: 2297-2303.

38. Aapro MS, Grunberg SM, Manikhas GM (2006) A phase III, doubleblind, randomized trial of palonosetron compared with ondansetron in preventing chemotherapy- induced nausea and vomiting following highly emetogenic chemotherapy. Ann Oncol 17: 1441-1449.

39. Saito M, Aogi K, Sekine I (2009) Palonosetron plus dexamethasone versus granisetron plus dexamethasone for prevention of nausea and vomiting during chemotherapy: a double- blind, double- dummy, randomised, comparative phase III trial. Lancet Oncol 10: 115-124.

40. Eisenberg P, Figueroa- Vadillo J, Zamora R (2003) Improved prevention of moderately emetogenic chemotherapy- induced nausea and vomiting with palonosetron, a pharmacologically novel 5-HT3 receptor antagonist: results of a phase III, single- dose trial versus dolasetron. Cancer 98: 2473-2482.

41. Gonullu G, Demircan S, Demirag MK, Erdem D, Yucel I (2012) Electrocardiographic findings of palonosetron in cancer patients. Support Care Cancer 20: 1435-1439.

42. Morganroth J, Flaharty KK, Parisi S, Moresino C (2016) Effect of single doses of IV palonosetron, up to $2.25 \mathrm{mg}$, on the QTc interval duration: a double- blind, randomized, parallel group study in healthy volunteers. Support Care Cancer 24: 621.

43. Basch E, Prestrud AA, Hesketh PJ, Kris MG, Feyer PC, et al. (2011) Antiemetics: American Society of Clinical Oncology clinical practice guideline update. J Clin Oncol 29: 4189-4198.

44. Hesketh PJ, Bohlke K, Lyman GH, Basch E, Chesney M, et al. (2016) Antiemetics: American Society of Clinical Oncology Focused Guideline Update. J Clin Oncol 34: 381-386.

45. National Comprehensive Cancer Network (NCCN) (2016) NCCN Clinical practice guidelines in oncology.

46. dos Santos LV, Souza FH, Brunetto AT, Sasse AD, da Silveira Nogueira Lima JP (2012) Neurokinin-1 receptor antagonists for chemotherapyinduced nausea and vomiting: a systematic review. J Natl Cancer Inst 104: 1280-1292.

47. Hesketh PJ, Grunberg SM, Gralla RJ (2003) The oral neurokinin-1 antagonist aprepitant for the prevention of chemotherapy- induced nausea and vomiting: a multinational, randomized, double- blind, placebo- controlled trial in patients receiving high- dose cisplatin- the Aprepitant Protocol 052 Study Group. J clin oncol 21: 4112-4119.
48. Poli-Bigelli S, Rodrigues-Pereira J, Carides AD (2003) Addition of the neurokinin 1 receptor antagonist aprepitant to standard antiemetic therapy improves control of chemotherapy- induced nausea and vomiting. Results from a randomized, double- blind, placebo- controlled trial in Latin America. Cancer 97: 3090-3098.

49. Hesketh PJ, Schnadig ID, Schwartzberg LS (2016) Efficacy of the neurokinin1 receptor antagonist rolapitant in preventing nausea and vomiting in patients receiving carboplatin- based chemotherapy. Cancer 122: 2418 .

50. Tanioka M, Kitao A, Matsumoto K (2013) A randomised, placebocontrolled, double-blind study of aprepitant in nondrinking women younger than 70 years receiving moderately emetogenic chemotherapy. Br J Cancer 109: 859

51. Yahata H, Kobayashi H, Sonoda K (2016) Efficacy of aprepitant for the prevention of chemotherapy- induced nausea and vomiting with a moderately emetogenic chemotherapy regimen: a multicenter, placebocontrolled, double- blind, randomized study in patients with gynecologic cancer receiving paclitaxel and carboplatin. Int J Clin Oncol 21: 491.

52. Ito Y, Karayama M, Inui N, Kuroishi S, Nakano H, et al. (2014) Aprepitant in patients with advanced non-small-cell lung cancer receiving carboplatin-based chemotherapy. Lung Cancer 84: 259-264.

53. Campos D, Pereira JR, Reinhardt RR, Carracedo C, Poli S, et al. (2001) Prevention of cisplatin-induced emesis by the oral neurokinin-1 antagonist, MK-869, in combination with granisetron and dexamethasone or with dexamethasone alone. J Clin Oncol 19: 1759-1767.

54. Shadle CR, Lee Y, Majumdar AK, Petty KJ, Gargano C, et al. (2004) Evaluation of potential inductive effects of aprepitant on cytochrome P450 3A4 and 2C9 activity. J Clin Pharmacol 44: 215-223.

55. Hesketh PJ, Rossi G, Rizzi G (2014) Efficacy and safety of NEPA, an oral combination of netupitant and palonosetron, for prevention of chemotherapy- induced nausea and vomiting following highly emetogenic chemotherapy: a randomized dose- ranging pivotal study. Ann Oncol 25: 134.

56. Gralla RJ, Bosnjak SM, Hontsa A, Balser C, Rizzi G, et al. (2014) A phase III study evaluating the safety and efficacy of NEPA, a fixed-dose combination of netupitant and palonosetron, for prevention of chemotherapy-induced nausea and vomiting over repeated cycles of chemotherapy. Ann Oncol 25: 1333-1339.

57. Ioannidis JP, Hesketh PJ, Lau J (2000) Contribution of dexamethasone to control of chemotherapy-induced nausea and vomiting: a meta-analysis of randomized evidence. J Clin Oncol 18: 3409-3422.

58. Chiu L, Chow R, Popovic M, Navari RM, Shumway NM, et al. (2016) Efficacy of olanzapine for the prophylaxis and rescue of chemotherapyinduced nausea and vomiting (CINV): a systematic review and metaanalysis. Support Care Cancer 24: 2381-2392.

59. Navari RM, Qin R, Ruddy KJ, Liu H, Powell SF, et al. (2016) Olanzapine for the Prevention of Chemotherapy-Induced Nausea and Vomiting. N Engl J Med 375: 134-142.

60. Mizukami N, Yamauchi M, Koike K (2014) Olanzapine for the prevention of chemotherapy- induced nausea and vomiting in patients receiving highly or moderately emetogenic chemotherapy: a randomized, doubleblind, placebo- controlled study. J Pain Symptom Manage 47: 542.

61. Roila F, Molassiotis A, Herrstedt J, Aapro M, Gralla RJ, et al. (2016) 2016 MASCC and ESMO guideline update for the prevention of chemotherapy- and radiotherapy-induced nausea and vomiting and of nausea and vomiting in advanced cancer patients. Ann Oncol 27: v119-119v133.

62. Kris MG, Gralla RJ, Clark RA (1987) Antiemetic control and prevention of side effects of anti- cancer therapy with lorazepam or diphenhydramine when used in combination with metoclopramide plus dexamethasone. A double- blind, randomized trial. Cancer 60: 2816-2822.

63. Smith LA, Azariah F, Lavender VT, Stoner NS, Bettiol S (2015) Cannabinoids for nausea and vomiting in adults with cancer receiving chemotherapy. Cochrane Database Syst Rev : CD009464. 
Citation: Sharma M, Bajpai J (2017) Chemotherapy Induced Nausea and Vomiting: Fear Makes the Wolf Bigger than He is. J Carcinog Mutagen 8: 282. doi:10.4172/2157-2518.1000282

Page 7 of 7

64. Hesketh PJ, Aapro M, Street JC, Carides AD (2010) Evaluation of risk factors predictive of nausea and vomiting with current standard-of care antiemetic treatment: analysis of two phase III trials of aprepitant in patients receiving cisplatin-based chemotherapy. Support Care Cancer 18: 1171-1177.

65. Molassiotis A, Aapro M, Dicato M (2014) Evaluation of risk factors predicting chemotherapy-related nausea and vomiting: results from a
European prospective observational study. J Pain Symptom Manage 47: 839-848.

66. Hu Z, Liang W, Yang Y (2016) Personalized Estimate of ChemotherapyInduced Nausea and Vomiting: Development and External Validation of a Nomogram in Cancer Patients Receiving Highly/Moderately Emetogenic Chemotherapy. Medicine 95: e2476. 